\title{
STUDI POTENSI PEMBANGKIT LISTRIK MINIHYDRO SISTEM TRANSMISI AIR BAKU PDAB UNIT BREGAS
}

\author{
Arya Rezagama*, Mochtar Hadiwidodo \\ Program Studi Teknik Lingkungan, Fakultas Teknik, Universitas Diponegoro \\ JI. Prof Soedharto No 1, Tembalang, Semarang. \\ Email: arya_tl@ft.undip.ac.id
}

\begin{abstract}
ABSTRAK
Distribusi pelayanan listrik di Indonesia hingga kini masih belum merata. Banyak desa-desa di pegunungan yang masih terbatas dalam mengakses pasokan listrik. Salah satu alternatif solusinya ialah dengan memanfaatkan beda ketinggian sistem perpipaan transmisi air baku. Jaringan transmisi PDAB Tirta Utama Jateng Unit Bregas teridiri atas tiga jalur perpipaan meliputi jalur Eksisting, Bregas I, dan Bregas II memiliki 34 Bak Pelepas Tekan yang bisa ditanamkan Pembangkit Listrik Minihydro. Survei lapangan dilakukan dari mata air hingga lokasi Reservoir Yamansari menggunakan GPS. Pengukuran debit aliran pipa menggunakan alat Ultrasonik Flowmeter. Analisis hidrolika perpipaan dihitung dengan formula Hazen-Williams. Alternatif lokasi terbaik yang akan dimanfaatkan potensinya sebagai pembangkit listrik tenaga mikrohidro/minihidro adalah ruas perpipaan BPT III A - BPT III B pada jalur Bregas I dengan potensi daya yang dihasilkan 434,24 kW, kemudian ruas perpipaan Chamber Kalibakung - BPT III A pada jalur Bregas I dengan potensi daya yang dihasilkan 303,71 kW. Kondisi jalur Bergas II masih belum optimal dimana debit yang beroperasi sekarang hanya 150 l/det dapat ditingkatkan menjadi 250 I/det. Ruas perpipaan BPT 6 - BPT 7 pada jalur Bregas II dengan potensi daya yang dihasilkan $227 \mathrm{~kW}$. Sedangkan sistem Bergas Eksisting tidak direkomendasikan untuk PLTM karena kondisi pipa yang sudah buruk dan kehandalan debit yang kurang baik dari sumbernya.
\end{abstract}

Kata kunci: Listrik, Pipa Transmisi, Air Minum

\section{PENDAHULUAN}

Pertambahan penduduk dan pendapatan domestik bruto di Indonesia setiap tahunnya akan berdampak pada meningkatkan kebutuhan energi listrik. Berdasarkan hasil proyeksi kebutuhan listrik dari tahun 2003 s.d. 2020 yang dilakukan PT PLN (Persero) dan Tim Energi BPPT, terlihat bahwa rata-rata kebutuhan listrik di Indonesia tumbuh sebesar $6,5 \%$ per tahun dimana sektor rumah tangga tumbuh sebesar $6,9 \%$ per tahun. Laju pertumbuhan sektor rumah tangga dipicu oleh rasio elektrifikasi dari berbagai daerah yang masih relatif rendah. Berdasarkan Indonesia Energy Outlook \& Statistics 2004 dan RUKN 2004-2013 menunjukkan besarnya rata-rata rasio elektrifikasi di Indonesia pada tahun 2008 menjadi 63,5\%, kemudian tahun 2013 meningkat menjadi $75 \%$ (Muchlis dan Permana, 2005)
Sasaran pengembangan energi nasional dan bauran energi yang optimal sampai tahun 2025 secara umum telah ditetapkan pada Peraturan Presiden No. 5 Tahun 2006. tentang Kebijakan Energi Nasional (KEN) . Sasaran bauran hingga 2050, antara lain peran energi baru terbarukan ditingkatkan menjadi $25 \%$ pada tahun 2025 (Visi 25/25) dan $40 \%$ pada tahun 2050 , rasio elektrifiasi $100 \%$ pada tahun 2020. (ESDM 2012) Jumlah masyarakat yang belum mendapatkan akses terhadap listrik masih 87,69 juta penduduk. Ketergantungan terhadap minyak masih dominan mencapai 49,7\% sementara pemanfaatan energi baru terbarukan (EBT) masih sekitar 6\% (ESDM, 2012).

Distribusi pengaliran listrik di Indonesia masih belum merata. Banyak desa-desa terpencil masih terbatas dalam mengakses pasokan listrik. Daerah yang berlokasi jauh dari sumber pembangkit memiliki tingkat 
kehilangan energi yang cukup tinggi pada proses penyalurannya. Maka diperlukan suatu alternatif sumber energi terbarukan yang lokasinya berada di daerah terpencil serta kapasitas yang kecil. Penggunaan teknologi pembangkit dari energi baru dan terbarukan skala kecil lebih cocok untuk dikembangkan di wilayah yang jauh dari sumber pembangkit.

Pembangkit listrik tenaga air ukuran kecil menjadi alternatif solusi permasalahan tersebut. Ada berbagai macam sumber air yang bisa digunakan sebagai pembangkit listrik, diantaranya sungai, irigasi, waduk, bendungan. Untuk pembangkit listrik yang memanfaatkan sungai, irigasi, waduk, dan bendungan sudah banyak dimanfaatkan oleh masyarakat. Namun untuk pembangkit listrik yang memanfaatkan energi dari dari jaringan pipa transmisi PDAM belum banyak dikembangkan di Indonesia. Salah satu potensi pembangkit energi listrik yang memanfaatkan jaringan pipa transmisi adalah Sistem Perpipaan Transmisi Perusahaan Daerah Air Bersih (PDAB) di Bregas Kabupaten Tegal.

Konsep pembangkit listrik menggunakan jaringan pipa transmisi PDAM adalah memanfaatkan beda ketinggian dari sumber ke daerah pelayanan. Kondisi eksisting jaringan pipa di bregas terdapat Bak Pelepas Tekan (BPT) untuk menghilangkan tekanan pada aliran air pada beda ketinggian yang cukup signifikan. Konsep pengembangannya ialah dengan memasukkan turbin ke dalam pipa sebelum Bak Pelepas Tekan ( BPT ) untuk mengambil energi listriknya. Selain itu lokasi yang berada di pedesaan akan meningkatkan ekses listrik di daerah sekitar.

Penelitian ini bertujuan untuk mengidentifkasi besaran energi listrik yang bisa di hasilkan dari sistem pipa transmisi. Kemudian dilakukan optimasi dengan variasi debit yang dapat dioptimalkan. Selain itu dikaji pula faktor kondisi eksisting yang menjadi tantangan dalam pemasangan PLTM.

\section{METODOLOGI}

Lingkup wilayah penelitian berada pada sistem tramnsisi Bregas jalur eksisting, jalur 1 dan 2 PDAB Kabupaten Tegal. Penelitian ini dilakukan selama enam bulan (Mei November 2015). Survei pendahuluan dilakukan untuk mendapatkan gambaran umum mengenai sistem transmisi Bergas PDAB Tegal. Kegiatannya meliputi survei lapangan, diskusi dengan pengelola Sistem dan mempersiapkan rencana detail bersama-sama dengan tim. Peralatan yang digunakan meliputi Watermeter portable Infrasonik, Pressure Gauge, Gobal Positioning System (GPS), Roll Meteran, Peta Rupabumi Bakosurtanal.

Penelusuran jalur pipa transmisi dimulai dari Mata air, Bak Pengumpul, Bak Pelepas Tekan hingga Reservoir Yamansari. Survei mengambil data koordinat lokasi pipa dengan menggunakan GPS. Selain itu survei memetakan kondisi lapangan dari daerah yang dilalui, menentukan titik kritis tekanan, penandaan lokasi Bak Pelepas Tekan. Pengukuran debit aliran pipa menggunakan alat Ultrasonik Flowmeter.

Jenis turbin yang digunakan tidak dibahas mendalam dalam penelitian ini. Tenaga potensial teoritis suatu aliran yang mempunyai tinggi sebesar $H(m)$ dan kapasitas debit sebesar $Q\left(\mathrm{~m}^{3} /\right.$ detik) maka daya ( Pnet ) secara teoritis dihitung dengan persamaan :

$$
\text { Pnet }=\mathrm{g} \times \mathrm{Q} \times \mathrm{H} \times \eta(\mathrm{kW})
$$

Dalam analisis hidrolika aliran pada saluran pipa untuk mengetahui kebutuhan tinggi tekan yang sesuai dengan karakteristik sistem pemasangan dan dimensi pipa dapat ditelusuri dengan pendekatan formulasi Hazen-Williams (Mays, 2000) yang juga bisa dihitung sebagai headloss major sesuai persamaan berikut:

$$
h f=\frac{10,675 \times Q^{1,852}}{C h^{1,85} \times D^{4,8704}} x L
$$

Perhitungan kondisi hidrolik pipa Sistem Transmisi adalah kecepatan aliran dan headloss (kehilangan energi) pada pipa. Data kecepatan, tekanan, dan headloss akan digunakan sebagai indikator kekuatan pipa dalam menahan kekuatan/daya hidrolik yang bisa merusak kondisi pipa. Selisih headloss dengan beda tinggi antara BPT menghasilkan ketinggian bersih yang dihitung sebagai HEAD turbin. Nilai kekasaran pipa didasarkan pada jenis dan umur dari pembangunan (Walski, et al., 2006). Pengaturan debit menggunakan kondisi optimal yang berbeda dengan kondisi debit eksisting. 


\section{HASIL DAN PEMBAHASAN}

Sistem transmisi PDAB Tirta Utama Jateng terdapat 3 jalur yang sudah terbangun dan 1 jalur yang masih dalam tahap pembangunan. Ketiga jalur tersebut adalah jalur eksiting, Bregas I, dan Bregas II. Jalur eksisting mulai dibangun pada tahun 1900 dan beroperasi pada tahun 1993, Bregas I dibangun tahun 2012 dan beroperasi tahun 2013, Bregas II dibangun pada tahun 2013 dan beroperasi pada tahun 2014.Jaringan transmisi eksisting di Bregas menggunakan sumber air baku dari Mata Air Kaligiri dengan debit kapasitas 252 liter/detik sengan ketinggian 1.045 mdpl. Jaringan transmisi ini berakhir di Reservoir Lebaksiu di elevasi 168,6 mdpl melalui 6 buah bak pelepas tekan dan memiliki panjang pipa sekitar $26,2 \mathrm{~km}$. Sistem ini mulai aktif dioperasikan pada Bulan November 1992. Pada tahun 2010, terdapat penambahan mata air Gombong dengan kapasitas debit $125 \mathrm{l} / \mathrm{s}$ yang dialirkan menuju BPT 4. Pada sistem jaringan transmisi sudah terbilang tua ini menggunakan pipa berjenis steel dan asbes sehingga sering terjadi kerusakan pipa, kebocoran air atau pergeseran pipa.

Jaringan transmisi Bregas I PDAB Tirta Utama Jateng memiliki tiga sumber air baku yang terletak di Kecamatan Bojong Kabupaten Tegal yaitu mata air kemadu, mata air mau dan mata air serang dengan total pengambilan debit mencapai $250 \mathrm{l} / \mathrm{s}$. Secara umum Jalur Bregas 1 memiliki panjang pipa transmisi kurang lebih 20,5 $\mathrm{km}$ dari mata air sampai reservoir Yamansari dan memiliki tujuh unit Bak Pelepas Tekan (BPT) yaitu BPT 1a, BPT 1b,BPT 2a,BPT 2b,BPT 3a,BPT 3b,dan BPT 3c. Sistem Transmisi Jalur Bregas 1 sebagian besar telah menggunakan pipa PVC, serta beberapa ruas yang menggunakan pipa steel maupun pipa GIP pada tekanan yang tinggi atau medan yang ekstrim.

Sedangkan Sistem Transmisi Jalur Bregas II terdiri dari 2 bangunan broncapturing, 1 bak pengumpul, 16 BPT, dan 1 Chamber. Dengan ukuran variatif $400 \mathrm{~mm}$ dan $500 \mathrm{~mm}$, pipa Sistem Transmisi Jalur Bregas II berjenis Steel dan PE. Sistem penyaluran transmisi jalur Bregas II menggunakan sistem gravitasi dengan sumber air baku Mata Air Suci yang memiliki elevasi $+1885 \mathrm{mdpl}$ dan debit 1119 I/s. Namun pada kondisi saat ini hanya dimanfaatkan $150 \mathrm{l} / \mathrm{det}$ karena perizinan ke warga dan kebutuhan pelayanan yang belum terserap dengan penuh.

Sistem Jaringan Bergas eksisting, dilakukan pengukuran pada Chamber Serang mengggunakan water meter dan pada ruas pipa setelah Chamber kalibakung menggunakan Ultra Sonic Flow Meter (UFM). Nilai keakuratan dari alat ultrasonic flow meter pada pengukuran debit hanya $55 \%-60 \%$, yang artinya data tersebut tidak sepenuhnya valid karena dari grafik memiliki fluktuasi yang rentangnya terlalu jauh. Ada beberapa hal yang menghambat alat untuk membaca debit secara tepat diantaranya adalah umur pipa, kondisi pipa, turbulensi air dalam pipa, dan kemampuan sensor. Umur pipa yang sudah lama akan mempengaruhi beberapa aspek teknik seperti korosi, kebocoran, kerusakan, serta pengaruhnya terhadap kondisi hidrolik. Lapisan dalam pipa yang sudah berumur tua akan semakin tebal akan semakin sulit untuk membaca debit secara akurat (Hickey, 2008). pengambilan angka debit pada data di atas menggunakan rerata angka yang mungkin dari debit sumber mata air yang berjumlah $308 \mathrm{l} / \mathrm{s}$.

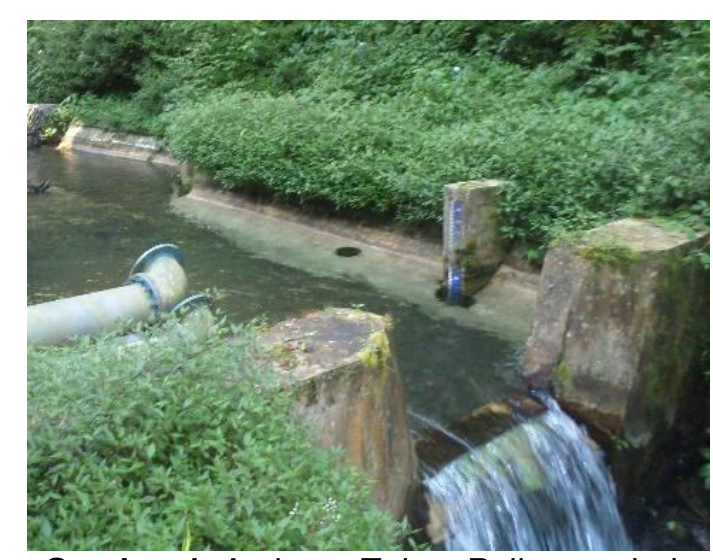

Gambar 1. Ambang Tajam Pelimpas dari Limpasan Mata Air Suci jalur Bregas 1 yang masih bisa dioptimalkan

Pengukuran pada Chamber Serang Jalur Bergas I dengan UFM di dapatkan nilai rata-rata 236,53 l/det didapatkan hasil dengan tingkat kepercayaan $80 \%$ yang cukup baik. Sedangkan debit Sistem Transmisi Jalur Bregas II terukur (dengan menggunakan alat ultrasonic flow meter) rata-rata 152 liter/detik, kecepatan aliran $0,776-1,213 \mathrm{~m} / \mathrm{s}$. Desain eksisting hidrolik pipa pada keseluruhan sistem tranmisi 
masih mampu menahan kecepatan aliran yang terjadi dan memiliki cukup energi yang dapat digunakan untuk pembangkit listrik.

Jaringan transmisi jalur Bergas eksisting memiliki 2 calon lokasi yang layak untuk pembangunan PLTMH yang berada pada BPT 6 dengan daya yang dihasilkan sekitar 212,7 KWh serta sebelum reservoir Lebaksiu sebesar 133,8 KWh. Sedangkan untuk jalur eksisting terjadi tren penurunan debit dari beberapa mata air dari pengamatan beberpa tahun terakhir. Sistem Transmisi yang terakhir adalah Jalur Bregas I, jika ditinjau dari Studi Kelayakan Investasi SPAM Regional Bregas produksi air bersih sampai tahun 2030 sebesar 250 liter/detik.

Kondisi hidrolis perpipaan sistem transmisi jalur eksisting masih terbilang aman untuk aspek kecepatan alir karena telah memenuhi syarat diantaranya kecepatan dalam rentang $0,3 \mathrm{~m} / \mathrm{s}-3 \mathrm{~m} / \mathrm{s}$ akan tetapi tekanan dalam pipa terdapat potensi pipa pecah pada ruas mata air Kaligiri - BPT 1 sebesar 105,1 m, BPT 1 BPT 2 sebesar 137,4 m, BPT 5 - BPT 6 sebesar 97,8 m , mata air Gombong - BPT 4 sebesar 101,1 dikarenakan kuat tekan water hammer jika dipasang turbin listrik.

Analisa kondisi hidrolik Sistem Transmisi Jalur Bregas । memiliki kecepatan alir berkisar antara $0,89 \mathrm{~m} / \mathrm{s}-$ $1,88 \mathrm{~m} / \mathrm{s}$ dan untuk tekanan kerja pada pipa berkisar antara 34,2 mka - 109,7 mka. Tiga ruas pipa yang memiliki tekanan yang paling tinggi adalah BPT $2 a-$ BPT $2 b$, BPT 3a - BPT 3b, dan BPT 3c - Reservoir Yamansari.

Analisis hidrolik dengan debit optimal pada Sistem Transmisi Jalur Bregas II sebesar 250 liter/detik seperti pada debit rencana maksimal produksi PDAB (RISPAM Bregas). Namum hingga saat ini masih beroperasi sekitar $150 \mathrm{l} / \mathrm{det}$. Kondisi hidrolik yang dihasilkan adalah kecepatan aliran $1,27-1,99 \mathrm{~m} / \mathrm{s}$, dan headloss di tiap ruas perpipaan masih di bawah nilai head statis dengan nilai 1,01 - 45,78 meter. Sedangkan potensi energi yang dihasilkan mayoritas di tiap ruas perpipaan memiliki daya di atas $120 \mathrm{~kW}$ (kapasitas minihidro/kriteria layak), rentang nilai potensi energi yang terdapat pada sistem transmisi Jalur Bregas II berkisar antara $83,28 \mathrm{~kW}-248,97 \mathrm{~kW}$.

Sistem transmisi PDAB Jalur II memiliki potensi yang paling baik dibandingkan dengan jalur Bergas eksisting dan Bergas
II. Optimalisasi debit sesuai dengan ketersediaan jumlah debit berlebih pada mata air dan Rencana Induk Sistem Penyediaan Air Minum (RISPAM) regional Bregas. Pada Sistem Transmisi Jalur Bregas II, jika ditinjau dari Studi Kelayakan Investasi SPAM Regional Bregas tahun 2011 maka ketersediaan mata air suci hingga tahun terakhir Rencana Induk (tahun 2030) adalah 250 liter/detik,

Analisis pemilihan alternatif lokasi pemasangan turbin pembangkit listrik pada Sistem Transmisi Jalur Bregas II menghasilkan tiga lokasi terbaik yaitu ruas perpipaan BPT 6 - BPT 7 dengan potensi energi listrik $234 \mathrm{~kW}$, ruas perpipaan BPT 7 - BPT 8 dengan potensi energi listrik 188 $\mathrm{kW}$, dan ruas perpipaan BPT 9 -BPT 10 dengan potensi energi listrik $148 \mathrm{~kW}$.

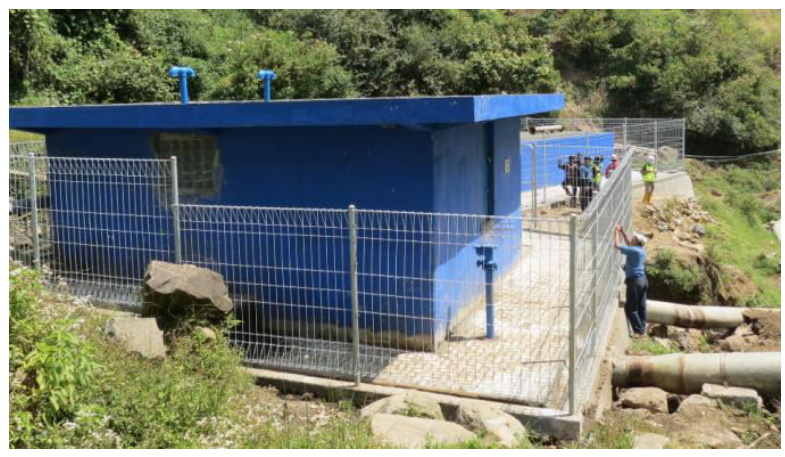

Gambar 2 BPT 2 Jalur Tranmisi Bergas II yang beropetensi menghasilkan listrik 253 kw.

Pada dokumen Rencana Induk Sistem Penyediaan Air Minum (RISPAM) tahun 2010, hingga tahun terakhir perencanaan tahun 2030, produksi air bersih oleh PDAB sebenarnya belum mampu memenuhi kebutuhan air bersih regional Bregas yang sudah diproyeksi untuk regional meliputi Kabupaten Brebes, Kota Tegal dan Kabupaten Tegal. Maka, untuk sementara kontrak kesepakatan antara PDAM dan PDAB pada tahun pengembangan tahap I (2010-2015) mengenai jumlah debit air bersih yang harus tersedia adalah sebesar 650 liter/detik. Kebutuhan air untuk wilayah perkotaan di tiga kabupaten/kota mencapai 1692 liter/detik pada tahun 2030.

Pada waktu studi di lapangan juga dilakukan pengamatan/perhitungan debit berlebih pada tiap sumber mata air yang dijadikan objek penelitian (Jalur Eksisting, Jalur Bregas I, dan Jalur Bregas II). 
Tabel 1. Rekap Analisa Hidrolika dan Besar Daya Listrik Yang dihasilkan Sistem Trasmisi Air Baku PDAB Jalur Eksisting, Jalur 1 dan Jalur 2

\begin{tabular}{|c|c|c|c|c|c|c|}
\hline Lokasi & $\begin{array}{c}\text { Debit } \\
(1 / s)\end{array}$ & $\begin{array}{l}\text { Beda TInggi } \\
\text { (m) }\end{array}$ & $\begin{array}{c}\text { Jarak } \\
(\mathrm{m})\end{array}$ & $\begin{array}{l}\text { Diameter } \\
(\mathrm{mm})\end{array}$ & $\begin{array}{c}\text { Sisa } \\
\text { Tekan }(\mathrm{m})\end{array}$ & $\begin{array}{c}\text { Output } \\
\text { Daya (Kwh) }\end{array}$ \\
\hline \multicolumn{7}{|c|}{ Jalur Eksisting } \\
\hline BPT 1 & 252 & 100 & 1,600 & 400 & 98 & 211 \\
\hline BPT 2 & 252 & 124 & 3,252 & 400 & 124 & 260 \\
\hline BPT 3 & 252 & 32 & 4,780 & 400 & 32 & 66 \\
\hline BPT 4 & 252 & 38 & 3,254 & 400 & 38 & 79 \\
\hline BPT 5 & 377 & 0 & 1,989 & 400 & 18 & 1 \\
\hline BPT 6 & 377 & 62 & 1,576 & 400 & 76 & 195 \\
\hline Reservoir Lebaksiu & 377 & 32 & 9,793 & 500 & 48 & 100 \\
\hline \multicolumn{7}{|c|}{ Jalur Bergas I } \\
\hline (Chamber Serang) & 250 & 65 & 620 & 400 & 59 & 123 \\
\hline BPT 1a & 250 & 65 & 2,840 & 400 & 46 & 97 \\
\hline BPT $1 b$ & 250 & 43 & 1,420 & 400 & 33 & 70 \\
\hline Chamber sarwan & 250 & 61 & 1,620 & 500 & 58 & 120 \\
\hline BPT 2a & 250 & 95 & 1,100 & 500 & 92 & 193 \\
\hline BPT $2 b$ & 250 & 44 & 1,930 & 500 & 39 & 82 \\
\hline Chamber kalibakung & 500 & 77 & 1,280 & 600 & 73 & 304 \\
\hline ВРT $3 a$ & 500 & 112 & 2,320 & 600 & 104 & 434 \\
\hline BPT 3b & 500 & 73 & 1,940 & 600 & 67 & 277 \\
\hline BPT 3c & 500 & 86 & 3,240 & 600 & 76 & 315 \\
\hline \multicolumn{7}{|c|}{ Jalur Bergas II } \\
\hline Mata Air Suci & 250 & 93 & 750 & 400 & 87 & 182 \\
\hline BPT 1 & 250 & 127 & 950 & 400 & 120 & 249 \\
\hline BPT 2 & 250 & 154 & 4,650 & 400 & 121 & 253 \\
\hline BPT 3 & 250 & 72 & 650 & 400 & 68 & 142 \\
\hline BPT 4 & 250 & 67 & 550 & 400 & 63 & 123 \\
\hline ВРТ 5 & 250 & 61 & 370 & 400 & 58 & 114 \\
\hline BPT 6 & 250 & 164 & 6,080 & 400 & 116 & 227 \\
\hline BPT 7 & 250 & 96 & 850 & 400 & 90 & 188 \\
\hline BPT 8 & 250 & 50 & 450 & 500 & 49 & 96 \\
\hline ВРТ 9 & 250 & 74 & 1,150 & 500 & 71 & 148 \\
\hline BPT 10 & 250 & 58 & 2,350 & 400 & 42 & 92 \\
\hline BPT 11 & 250 & 70 & 1,800 & 400 & 58 & 113 \\
\hline BPT 12 & 250 & 74 & 650 & 400 & 70 & 145 \\
\hline BPT 13 & 250 & 78 & 1,400 & 400 & 69 & 134 \\
\hline BPT 14 & 250 & 60 & 2,250 & 400 & 45 & 99 \\
\hline BPT 15 & 250 & 89 & 700 & 400 & 83 & 173 \\
\hline BPT 16 & 250 & 48 & 1,211 & 400 & 38 & 85 \\
\hline
\end{tabular}


Hasilnya didapat debit berlebih pada mata air banyumudal sebesar $413 \mathrm{~m}^{3} /$ detik dan mata air suci sebesar $385 \mathrm{~m}^{3} /$ detik, sedangkan Jalur Eksisting tidak terdapat debit berlebih yang mengalir ke sungai, debit mengalir hanya untuk irigasi persawahan di sekitar mata air Kaligiri.

\section{KESIMPULAN}

Alternatif lokasi terbaik yang akan dimanfaatkan potensinya sebagai pembangkit listrik tenaga mikrohidro/minihidro adalah ruas perpipaan BPT III A - BPT III B pada jalur Bregas I dengan potensi daya yang dihasilkan 434,24 kW, kemudian ruas perpipaan Chamber Kalibakung - BPT III A pada jalur Bregas I dengan potensi daya yang dihasilkan 303,71 kW. Kondisi jalur Bergas II masih belum optimal dimana debit yang beroperasi sekarang hanya $150 \mathrm{l} /$ det dapat ditingkatkan menjadi $250 \mathrm{l} / \mathrm{det}$. Ruas perpipaan BPT 6 - BPT 7 pada jalur Bregas II dengan potensi daya yang dihasilkan 227 kW. Sedangkan sistem Bergas Eksisting tidak direkomendasikan untuk PLTM karena kondisi pipa yang sudah buruk dan kehandalan debit yang kurang baik dari sumbernya.

\section{DAFTAR PUSTAKA}

ESDM. (2012). Kajian Indonesia Energy Outlook 2012. Jakarta : s.n., 2012.

Hickey, H. E. (2008). Water Supply Systems and Evaluation Methods. United Stated of America: U.S. Fire Administration, 2008.

Mays, L. W. (2000). Water Distribution System Handbook. USA : McGraw-Hill, 2000. ISBN 0071342133.

Muchlis, M. dan Permana, A. D. (2005). Proyeksi Kebutuhan Listrik PLN Tahun 2003 S.D 2020. OoCities.org. [Online] 2005.

http://www.oocities.org/markal_bppt/.

Walski, T. M., Methods, H. Chase, D. V., Savic, D. A., Grayman, W. M., Beckwith, S. and Koelle, E. (2006). Advanced Water Distribution Modeling And Management. s.I. : Bently Institute Press, 2006. 